\title{
ДІАГНОСТИКА ЯК ІНСТРУМЕНТ АНТИКРИЗОВОГО УПРАВЛІННЯ ПІДПРИЕМСТВОМ
}

\begin{abstract}
Анотація. Мета статті полягає в узагальненні існуючих підходів до проведення діагностики діяльності підприемства для підвищення ефективності антикризового управління ним. Аналізуючи, систематизуючи та узагальнюючи праці багатьох науковців, розкрито сутність поняття "діагностика" в антикризовому управлінні підприемством, виокремлено основні види діагностики та напрями її здійснення. У ході дослідження встановлено, що концептуальною основою діагностичних досліджень підприемства та самого процесу антикризового управління є багатоконтурна модель діагностики, яка складається 3 декількох етапів: експрес-діагностика, загальна діагностика, комплексна діагностика, системна діагностика. Експрес-діагностика передбачає проведення горизонтального та вертикального аналізу показників фрінансової звітності підприемства та їх динаміки, розрахунок фінансових коефіцієнтів (ліквідності та платоспроможності, фінансової стійкості, рентабельності, ділової активності). Загальна діагностика включає в себе основні елементи аналізу: зміни структури капіталу; ефективності використання виробничих ресурсів; стану оборотних активів. Комплексна діагностика передбачає проведення аналізу системи управління підприемством, параметрів взаємозв'язку, взаємозалежності чинників виробництва. На етапі системної діагностики проводиться аналіз ефективності організаційної структури підприемства на основі сформованих корпоративних норм.
\end{abstract}

Ключові слова: антикризове управління, експрес-діагностика, загальна діагностика, комплексна діагностика, системна діагностика.

Prus Yuliia, Sosnina Kateryna

V.N. Karazin Kharkiv National University

\section{DIAGNOSIS AS A TOOL OF ANTI-CRISIS MANAGEMENT OF THE ENTERPRISE}

Summary. The purpose of the article is to summarize the existing approaches to the diagnosis of the enterprise to improve the effectiveness of anti-crisis management. Analyzing, systematizing and generalizing the works of many scientists, the essence of the concept "diagnostics" in anti-crisis management of the enterprise is revealed, the main types of diagnostics and directions of its implementation are singled out. During the study it was found that the conceptual basis of diagnostic research of the enterprise and the process of anti-crisis management is a multi-circuit diagnostic model, which consists of several stages: express diagnostics, general diagnostics, complex diagnostics, system diagnostics. This model of diagnostics involves the implementation of a systematic approach to the analysis of the enterprise's state and allows to optimize the use of resources through a multi-step sequential diagnostic procedure with intermediate decisions. Express diagnostics involves horizontal and vertical analysis of financial statements of the enterprise and their dynamics, calculation of financial ratios (liquidity and solvency, financial stability, profitability, business activity). The paper summarizes the main indicators of the enterprise financial condition and provides calculation formulas for each of them. General diagnostics includes the main elements of the analysis: changes in the capital structure; efficient use of production resources; state of current assets. Its task is to identify the causes of the dynamics of production factors, analysis of indicators of resource efficiency and operation of the enterprise. Complex diagnostics involves the analysis of the enterprise management system, the parameters of the relationship, interdependence of factors of production. The analysis of efficiency of control system can be carried out by a method of a quantitative and qualitative estimation of its functional components on the basis of qualimetric model. At the stage of system diagnostics the analysis of organizational structure efficiency of the enterprise on the basis of the formed corporate norms is carried out. It involves assessing the effectiveness of management decisions, assessing the potential of available resources and the main economic institutions of the enterprise, actualized in its institutional norms, values, philosophy and mission.

Keywords: anti-crisis management, rapid diagnostics, general diagnostics, complex diagnostics, system diagnostics.

$\Pi^{-2 n}$ остановка проблеми. Неоднозначність та динамічна мінливість зовнішнього середовища, постійна трансформація ринкових механізмів та економічна турбулентність обумовлюють необхідність удосконалення інструментів управління діяльністю підприємства. Першочерговість вирішення цього завдання також пояснюється активним впровадженням технологій нового покоління, у т.ч. й управлінських. Зміна усталених підходів до забезпечення конкурентоспроможного розвитку підприемства за рахунок індивідуального підходу до кожного споживача вимагає впровадження не менш гнучкого антикризового управління. У зв'язку з цим, при дослідженні різноманітних аспектів удосконалення механізму управління діяльністю підприемства на перший план виходить проблема діагностики узгодження матеріальних, фрінансових та індрормаційних потоків між окремими складовими виробничої системи.

Аналіз літератури за тематикою дослідження дає підстави констатувати, що в розвинених країнах світу близько третини випадків банкрутства підприемства обумовлено впливом зовніш- 
ніх чинників, що підтверджує актуальність проведення діагностики стану підприемства задля попередження криз, його банкрутства та виявлення доцільності проведення профрілактичних заходів. За таких умов одним 3 найважливіших завдань антикризового управління стає діагностика ймовірності аномальних відхилень у діяльності підприемства задля вчасного прийняття корегувальних рішень. Концентруючи увагу управлінців на причинно-наслідкових зв'язках, діагностика виступає інструментом, який узагальнюе весь спектр подій в діяльності підприемства, які можуть привести його до того чи іншого кінцевого стану. При цьому з'являеться можливість оцінювання ймовірності їх звершення.

Аналіз останніх досліджень і публікацій. Питання кризи як закономірного явища розвитку економічної системи, концептуально обгрунтовано у працях У. Бівера, Дж. Кейнса, М. Кондратьева, Е. Альтмана, Д. Рікардо, Г. Спрінгейта, П. Самуельсона, Р.Дж. Хоутрі, М. Туган-Барановського, Й. Шумпетера та ін.

Сутність антикризового управління, особливості його реалізації у практичній діяльності підприємств розкрито у працях іноземних науковців: I. Ансофрфа, Л. Беркмана, П. Друкера, Р. Келлера, М. Мескона, А. Томпсона, А. Штангрета. Дослідженню теоретичних і прикладних засад антикризового управління підприємств присвячено також дослідження вітчизняних науковців: В. Амбросова, Р. Біловол, В. Гейця, М. Дем'яненка, А. Мазаракі, Н. Прокопенка, Т. Пуліна, Л. Ситника, О. Остапенко, С. Філиппова та інших.

Вказані праці містять ряд цінних і важливих думок як загального, так і часткового характеру, однак їх наявність не виключає подальшого вивчення проблеми, оскільки не усі питання висвітлені достатньою мірою та не 3 усіма твердженнями можна повністю погодитися.

Виділення не вирішених раніше частин загальної проблеми. Діагностика сталого розвитку підприемства, як і саме поняття "діагностика» не має загальноприйнятого визначення, а питання про методи діагностики в антикризовому управлінні залишаються на сьогоднішній день відкритими. У той же час результати діагностики діяльності підприємства викликають інтерес не лише у менеджерів, акціонерів, кредиторів, постачальників, споживачів та інших осіб при виборі найбільш надійних та перспективних ділових партнерів. Вона потрібна і для власної оцінки, яка дозволяе розпізнати ознаки погіршення стану функціонування, виявити причини їх виникнення, оперативно відреагувати на них та 3 більшою ймовірністю уникнути або зменшити ризик банкрутства шляхом своєчасно вживаних заходів для виведення підприємства 3 кризового стану. Від діагностики залежить не тільки едективність прийнятих управлінських рішень, а й сама можливість подальшого функціонування підприемства.

Діагностика та ощінка їі результатів є важливою складовою антикризового управління та антикризової політики щодо методичного обІрунтування процесу прийняття рішень на підприемствах. Усе вище зазначене обгрунтовуе необхідність подальшого розвитку концептуальних та методичних засад діагностики як інструмента підвищення ефрективності антикризового управління на різних етапах фрункціонування та розвитку підприємства як соціально-економічної системи.

Метою статті $є$ узагальнення існуючих підходів до проведення діагностики діяльності підприемства для підвищення едективності антикризового управління ним.

Виклад основного матеріалу. Кризові ситуації, наслідком яких може бути банкрутство підприемств, доцільно розглядати не як збіг несприятливих обставин (хоча для окремих підприемств це може бути і так), а як певну закономірність, властиву ринковій економіці. Кризові ситуації, якщо для їх подолання не було прийнято відповідних заходів, можуть призвести до надзвичайного розбалансування економічного організму підприемства та неспроможності фpiнансово забезпечувати свою діяльність, що кваліфрікуеться як банкрутство.

Як показує світовий досвід, антикризовий процес в умовах ринкової економіки $є$ керованим. У зв'язку 3 цим, доцільно виділити два поняття [5; 7]:

1. антикризове регулювання - це макроекономічна категорія, що означає заходи організаційно-економічного та нормативно-правового впливу з боку держави, спрямовані на захист підприемства від кризових ситуацій, запобігання банкрутства або ліквідащію підприемств у разі недощільності їх подальшого функціонування;

2. антикризове управління - це мікроекономічна категорія, яка характеризуе відносини, що складаються на рівні підприемства при його оздоровленні чи ліквідації, а також сукупність форм і методів реалізації антикризових процедур на конкретному підприемстві.

Термін "діагностика" походить від слова діагноз, яке в перекладі з грецького означає «розпізнавання», «визначення».

В економічній літературі діагностика неспроможності часто розуміється як специфічний вид економічного аналізу, який проводиться на неплатоспроможному підприемстві. Однак в загальному розумінні, діагностика - це інструмент отримання достовірної якісної інфрормащії про реальні можливості підприемства на будь-якій стадії кризи на основі особливих методів і механізмів менеджменту [1]. Вона служить для ідентифрікації причин зміни стану об'єкта, явища або процесу управління на основі проведених досліджень.

Діагностика $є$ одним з основних інструментів антикризового управління. Процес діагностики, як правило, носить дослідницький, пошуковий та пізнавальний характер і здійснюеться в часі та просторі на основі системного підходу.

Основний напрямок процесу діагностики зверху вниз: від аналізу показників складного комплексу до аналізу показників, складових його елементів, від аналізу результатів роботи підприемства до аналізу чинників.

Схему аналізу, побудовану за принципом «від загального до конкретного», представлено на рис. 1.

У ній відображено об'єднання методів діагностики і процесів управління розвитком підприємства як інструмент управління його економічною безпекою. При цьому важливо підкреслити, що однією з цілей діагностики є визначення іден- 


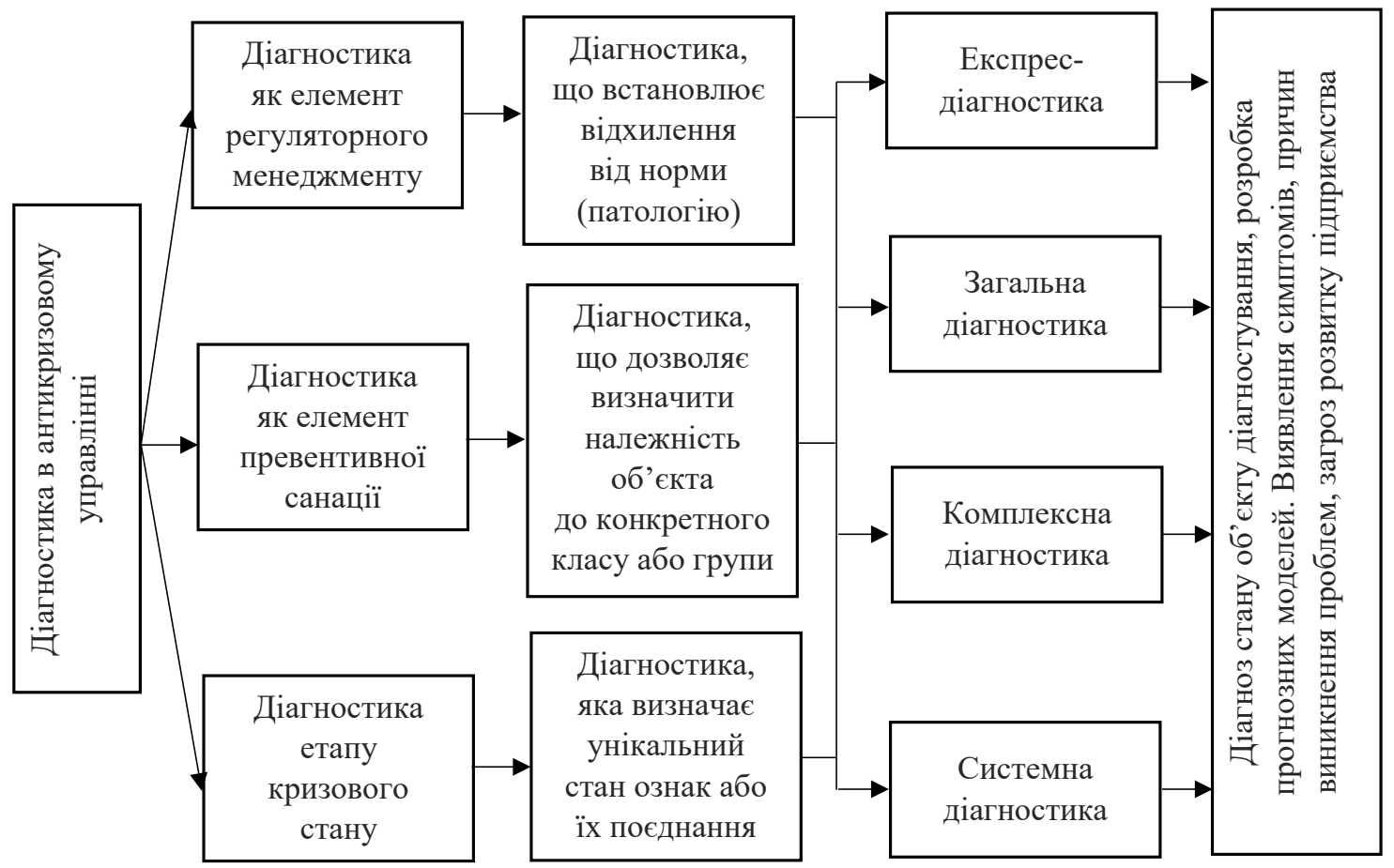

Рис. 1. Напрями та види діагностики

Джерело: складено авторами за даними [2; 4]

тичності та нівелювання диспропорщії параметрів розвитку підприемства. Це є необхідною вимогою подальшого розвитку. Звідси випливає, що діагностика $є$ як фоннкцією, так і специфрічної стадією антикризового управління.

Спільними завданнями діагностики є: дослідження фрінансового стану підприемства; визначення масштабів кризового стану й оцінка ймовірності банкрутства; вивчення та прогнозування чинників, що обумовлюють розвиток кризових процесів.

Особливий характер діагностики в антикризовому управлінні визначається гострим дефіцитом ресурсів (особливо часового чинника). Кон- цептуальною основою діагностичних досліджень підприемства i самого процесу антикризового управління є багатоконтурна модель діагностики, наведена на рис. 2.

Багатоконтурна модель діагностики передбачає реалізацією системного підходу при аналізі стану підприемства та дозволяе оптимізувати використання ресурсів за рахунок багатокрокової послідовної процедури діагностики 3 прийняттям проміжних рішень. Системний підхід проявляеться через послідовне наближення до виявлення причин тих чи інших кризових процесів. Зміст основних етапів діагностики представлено на рис. 3.

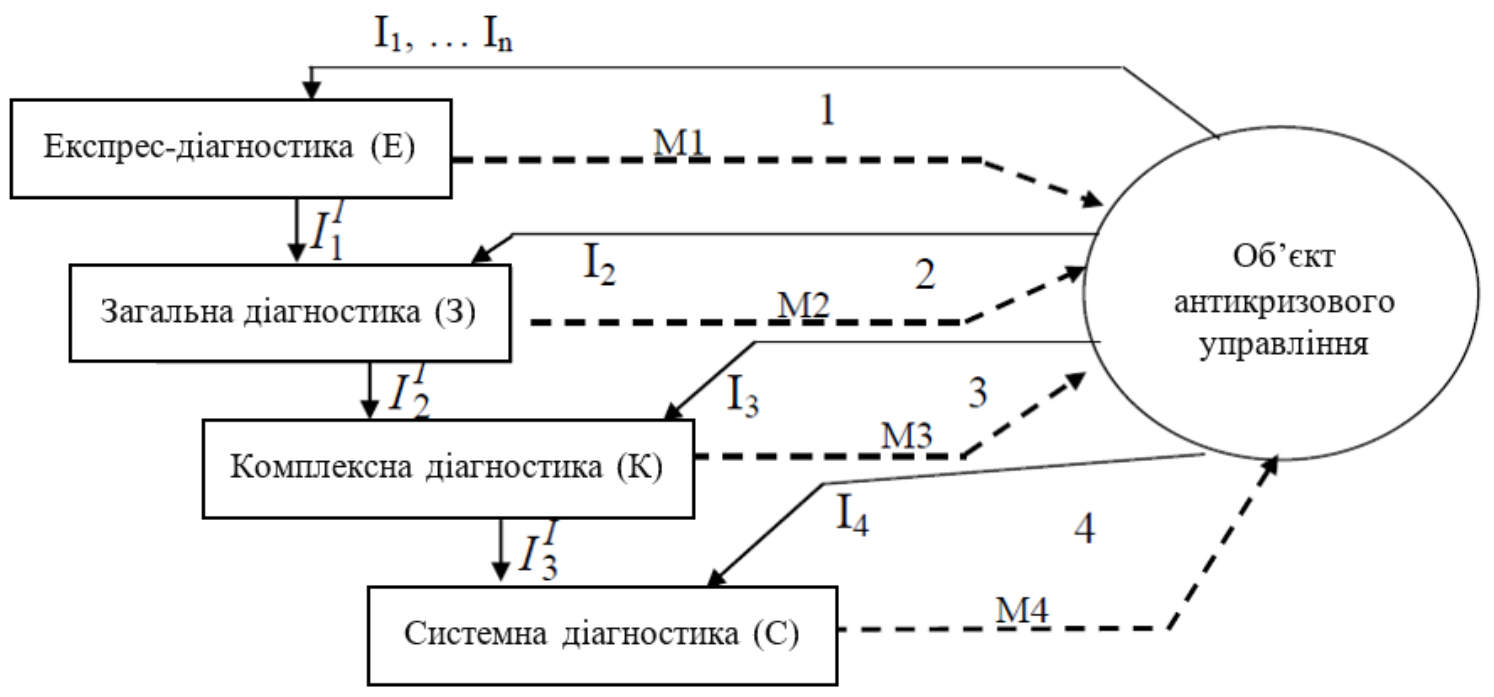

1, 2, 3, 4- етапи (контури) діагностики;

$\mathrm{I}_{1}, \ldots, \mathrm{I}_{\mathrm{n}}$ - інформація (тип параметрів стану) об'єкту антикризового управління;

$\mathrm{M}_{1}, \mathrm{M}_{2}, \mathrm{M}_{3}, \mathrm{M}_{4}$ - управлінський вплив за результатом відповідного етапу діагностики.

Рис. 2. Модель багатоконтурної діагностики в антикризовому управлінні 


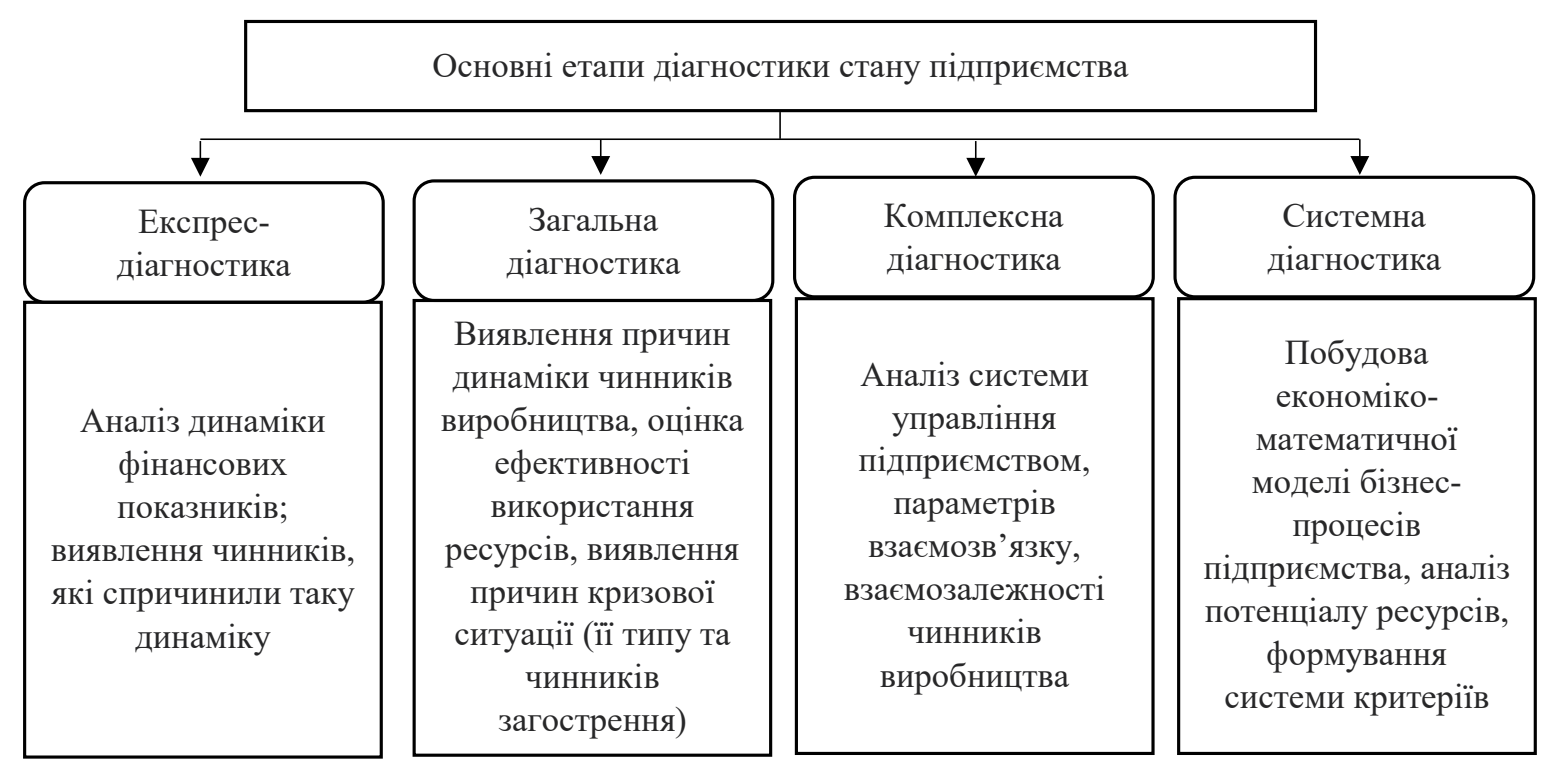

Рис. 3. Зміст основних етапів діагностики

Зупинимося детальніше на кожному з етапі діагностики стану підприемства.

Логіка експрес-аналізу фрінансово-господарської діяльності підприемства передбачає їі організацію у вигляді набору аналітичних процедур. Метою такого аналізу $є$ отримання загального уявлення про найбільш впливові чинники виробництва, проведення оперативної та наочної оцінки динаміки фрінансового стану підприемства.

Експрес-аналіз, як правило, включає декілька процедур:

1. Проведення оцінки динаміки виручки та собівартості реалізації продукщї. При виконанні умов «золотого правила економіки» прибуток повинен зростати більш високими темпами, ніж обсяги реалізації продукщї та темпи зростання активів відповідно:

$$
T_{n}>T_{\text {o }}>T_{a}>100 \%,
$$

де $T_{n}-$ темп зміни прибутку; $T_{s}-$ темп зміни виручки від продажу продукції; $T_{a}^{6}-$ темп зміни активів (майна) підприемства [3].

2. Горизонтальний та вертикальний аналіз показників фрінансової звітності підприємства та їх динаміка.

3. Розрахунок та аналіз фрінансових коефіціентів (ліквідності та платоспроможності; фрінансової стійкості; рентабельності; ділової активності).

Показники ліквідності та платоспроможності характеризують здатність підприемства відповідати за своїми зобов'язаннями. Ліквідність активів характеризує їх здатність перетворюватися в грошові кошти (величина, зворотна часу, необхідному для перетворення їх в грошові кошти).

Показники фрінансової стійкості характеризують здатність підприємства своєчасно проводити платежі, фрінансувати свою діяльність (як за рахунок власних, так і за рахунок позикових джерел).

Показники рентабельності (від нім. rentabel прибутковий) - система показників, що відображають кінцеві результати господарювання. Вони розраховуються як співвідношення ефректу орінансового результату з витратами або ресурсами, застосовуваними для досягнення цього ефекту. $\mathrm{y}$ якості показника економічного едекту, як правило, обирається один з показників прибутку (прибуток від реалізації, чистий прибуток, операційний прибуток тощо), а витрати або ресурси - представлені собівартістю, вартістю активів, розміром авансованого капіталу тощо.

Показники ділової активності «business activity» - система показників, які характеризують тривалість знаходження засобів в обороті, причому на етапі експрес-аналізу проводиться тільки кількісна оцінка показників ефективності використання матеріальних, трудових і фрінансових ресурсів.

Основні показники, які характеризують фінансовий стан підприемства, узагальнено авторами у табл. 1.

На етапі експрес-аналізу вже попередній аналіз даних дозволяе отримати основні змістовні висновки (керуючий вплив $\mathrm{M}_{1}$, див. рис. 2), минаючи етап загальної діагностики.

Розглядаючи загальну діагностику, доречно зазначити, що завданням даного етапу є виявлення причин динаміки чинників виробництва, аналіз показників ефективності використання ресурсів i фрункціонування підприемства, що включає аналіз параметрів як внутрішніх, так і зовнішніх умов діяльності підприемства (тип власності, розмір підприемства (частка ринку), кон'юнктури ринку, заборгованості за кредитами, дебіторської заборгованості, витрат на виробництво). Встановлюються причини наростання кризової ситуаціі, які включають визначення типу кризи, чинників її наростання тощо.

Загальна діагностика включає в себе основні елементи аналізу: зміни структури капіталу; стану і руху основних засобів (едективності використання виробничих ресурсів); стану оборотних активів.

Найбільш поширені показники едективності діяльності підприемства засновані на певному наборі параметрів і критеріїв їх оцінки. Перелік основних показників ефективності діяльності підприемства наведено в табл. 2.

На етапі комплексної діагностики проводиться побудова системи параметрів (якісних і кількісних) і правил, які адекватно відображають 
Система основних показників фінансового стану підприемства

\begin{tabular}{|c|c|c|}
\hline Назва показника & $\begin{array}{c}\text { Формула для } \\
\text { розрахунку }\end{array}$ & Умовні позначення \\
\hline \multicolumn{3}{|c|}{ Показники ліквідності та платоспроможності } \\
\hline Коефіцієнт поточної ліквідності, К $_{\text {пл }}$ & $K_{n n}=\frac{O A}{K 3}$ & $\begin{array}{l}\text { ОА - оборотні активи; } \\
\text { КЗ - короткострокові зобов'язання }\end{array}$ \\
\hline Коефіцієнт абсолютної ліквідності, $\mathrm{K}_{\text {ал }}$ & $K_{a l}=\frac{\Gamma K+K \Phi B}{K 3}$ & $\begin{array}{l}\text { ГК - грошові кошти; } \\
\text { КФВ - короткострокові фрінансові } \\
\text { вкладення; }\end{array}$ \\
\hline $\begin{array}{l}\text { Коефріціент критичної (термінової) ліквідності, } \\
\mathrm{K}_{\text {кл }}\end{array}$ & $K_{\kappa \imath}=\frac{O A-3-H B}{K 3}$ & $\begin{array}{l}\text { ОА - оборотні активи; } \\
\text { З - запаси; } \\
\text { НВ - незавершене виробництво }\end{array}$ \\
\hline Коефіцієнт покриття запасів, $\mathrm{K}_{\text {пз }}$ & $K_{n 3}=\frac{B O K+K 3}{3}$ & $\begin{array}{l}\text { ВОК - власний оборотний капітал; } \\
\text { 3- запаси }\end{array}$ \\
\hline \multicolumn{3}{|c|}{ Показники фбінансової стійкості } \\
\hline $\begin{array}{l}\text { Коефіціент забезпеченості власними } \\
\text { оборотними засобами, } \kappa_{\text {воз }}\end{array}$ & $K_{a r}=\frac{B O K}{O A}$ & $\begin{array}{l}\text { ВОК - власні оборотні кошти; } \\
\text { ОА - оборотні активи }\end{array}$ \\
\hline Коефіцієнт маневреності, $\mathrm{K}_{\mathrm{m}}$ & $K_{M}=\frac{4 O K}{B K}$ & $\begin{array}{l}\text { ЧОК - чистий оборотний капітал; } \\
\text { ВК - власний капітал }\end{array}$ \\
\hline Коефіціент фрінансового важеля, $\mathrm{K}_{\phi в}$ & $K_{\phi b}=\frac{B 3}{B K}$ & $\begin{array}{l}\text { ВЗ - власні зобов’язання; } \\
\text { ВК - власний капітал }\end{array}$ \\
\hline Коефіціент фрінансової стійкості, $K_{\phi c}$ & $K_{\phi c}=\frac{(В K+Д O)}{3 K}$ & $\begin{array}{l}\text { ВК - власний капітал; } \\
\text { ДО - довгострокові зобов'язання }\end{array}$ \\
\hline Коефіцієнт автономії, $\kappa_{\text {авт }}$ & $K_{a b m}=\frac{B K}{3 K}$ & ЗК - загальні вкладення \\
\hline \multicolumn{3}{|c|}{ Показники рентабельності } \\
\hline Рентабельність продажів, $\mathrm{R}_{\text {п }}$ & $\mathrm{R}_{n}=\frac{\Pi p}{B u p}$ & $\begin{array}{l}\text { Пр - прибуток від реалізації продукції; } \\
\text { Вир - обсяг отриманої виручки }\end{array}$ \\
\hline Рентабельність власного капіталу, $\mathrm{R}_{\text {вк }}$ & $\mathrm{R}_{c \kappa}=\frac{4 \Pi}{B K}$ & $\begin{array}{l}\text { ЧП - чистий прибуток; } \\
\text { ВК - власний капітал }\end{array}$ \\
\hline Рентабельність витрат, $\mathrm{R}_{\text {в }}$ & $\mathrm{R}_{6}=\frac{\Pi p}{B}$ & $\begin{array}{l}\text { Пр - прибуток від реалізації продукції; } \\
\text { В - обсяг витрат }\end{array}$ \\
\hline Прибуток на одну акцію, П & $\Pi_{a \kappa}=\frac{\left(Ч \Pi-Д_{n a}\right)}{N_{a}}$ & 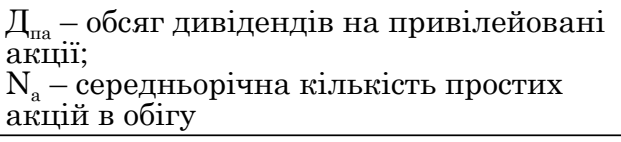 \\
\hline \multicolumn{3}{|c|}{ Показники ділової активності } \\
\hline Продуктивність праці, П п & $\Pi_{n}=\frac{V}{T}$ & $\begin{array}{l}\text { V - обсяг виробленої продукції; } \\
\text { Т - величина робочого часу, витраченого } \\
\text { на її виробництво }\end{array}$ \\
\hline Фондовіддача виробничих фондів, Ф & $\Phi=\frac{V}{B_{o \phi}}$ & $\begin{array}{l}\mathrm{B}_{\text {оф }} \text { - середньорічна вартість основних } \\
\text { виробничих фондів }\end{array}$ \\
\hline $\begin{array}{l}\text { Коефіцієнт загального обертання власного } \\
\text { капіталу, } \kappa_{\text {вк }}\end{array}$ & $K_{6 K}=\frac{V}{B K}$ & ВК - власний капітал \\
\hline Тривалість операційного циклу, T. & $T_{o}=\frac{O A \times t}{V}$ & $\begin{array}{l}\text { ОА - оборотні активи; } \\
\text { t - тривалість звітного періоду, що } \\
\text { аналізуеться }\end{array}$ \\
\hline Тривалість фінансового циклу, $\mathrm{T}_{\phi}$ & $T_{\phi}=T_{o}-T_{\kappa з}$ & $\begin{array}{l}\mathrm{T}_{\mathrm{rz}}-\text { період обороту короткострокових } \\
\text { зобов'язань }\end{array}$ \\
\hline
\end{tabular}

Джерело: побудовано авторами за даними [2; 3; 4]

специфіку конкретного об'єкта, тобто встановлення взаємозв'язку, взаємозалежності досліджуваних чинників. На основі отриманих даних у загальному випадку оцінюеться едективність фрункціонування: бізнес-процесів на підприемстві, системи управління (рефлексивних властивостей процесів управління), адекватності інституційних норм підприемства тощо.
Аналіз ефрективності систем управління може бути проведено методом кількісної та якісної оцінки фрункціональних складових системи управління на основі кваліметричної моделі. Вона передбачає побудову дерева фрункцій з конкретизацією завдань у підфункціях нижчих рангів шляхом декомпозиції основних елементів менеджменту (рис. 4). 
Показники ефективності діяльності підприемства

\begin{tabular}{|c|c|c|}
\hline Назва показника & Формула для розрахунку & Зміст показника \\
\hline $\begin{array}{l}\text { Рентабельність } \\
\text { активів (return on } \\
\text { assets, ROA) }\end{array}$ & ROA $=\frac{\text { Чистий прибуток }}{\text { Активи }}$ & $\begin{array}{l}\text { Фінансовий коефіціент, який характеризуе } \\
\text { віддачу від використання активів підприемства. } \\
\text { Він показуе здатність організації генерувати } \\
\text { прибуток без урахування структури його капіталу } \\
\text { (фінансового левериджу), якості управління } \\
\text { активами }\end{array}$ \\
\hline $\begin{array}{l}\text { Рентабельність } \\
\text { власного капіталу( } \\
\text { return on equity, ROE) }\end{array}$ & ROE $=\frac{\text { Чистий прибуток }}{\text { Власний капітал }}$ & $\begin{array}{l}\text { Фінансовий коефіціент, який характеризуе } \\
\text { ефективність використання власного капіталу. } \\
\text { Показуе, яка віддача (норма прибутку) на } \\
\text { вкладений власний капітал }\end{array}$ \\
\hline $\begin{array}{l}\text { Рентабельність } \\
\text { iнвестицій (return on } \\
\text { investment, ROI) }\end{array}$ & ROI $=\frac{\text { Чистий прибуток }}{\text { Інвестиції }}$ & $\begin{array}{l}\text { Фінансовий коефіцієнт, який ілюструє рівень } \\
\text { прибутковості або збитковості бізнесу, враховуючи } \\
\text { суму зроблених в цей бізнес інвестицій }\end{array}$ \\
\hline $\begin{array}{l}\text { Рентабельність } \\
\text { продажу (return on } \\
\text { sales, ROS) }\end{array}$ & $R O S=\frac{\text { Чистий прибуток }}{\text { ЧД від реалізаиії }}$ & $\begin{array}{l}\text { Коефріцієнт показуе, яку суму операційного } \\
\text { прибутку одержуе підприемство з кожної гривні } \\
\text { проданої продукції. Іншими словами, скільки } \\
\text { залишається в підприємства після покриття } \\
\text { собівартості продукції }\end{array}$ \\
\hline $\begin{array}{l}\text { Економічна додана } \\
\text { вартість (есопотіс } \\
\text { value added, EVA) }\end{array}$ & $\begin{array}{l}\text { EVA = NOPAT - WACC * IC, } \\
\text { де NOPAT - чистий операційний } \\
\text { прибуток після сплати податків; } \\
\text { WACC - середньозважена } \\
\text { вартість капіталу; } \\
\text { IC - інвестований капітал }\end{array}$ & $\begin{array}{l}\text { Економічна додана вартість (EVA) - прибуток } \\
\text { підприемства від звичайної діяльності за } \\
\text { вирахуванням податків, зменшений на величину } \\
\text { плати за весь інвестований у підприемство } \\
\text { капітал }\end{array}$ \\
\hline $\begin{array}{l}\text { Додана ринкова } \\
\text { вартість (market value } \\
\text { added, MVA) }\end{array}$ & $\begin{array}{c}\text { MVA = Ринкова вартість } \\
\text { компанії - Власний капітал }\end{array}$ & $\begin{array}{l}\text { MVA дозволяє оцінити, як фінансовий ринок } \\
\text { зараз приймає майбутні результати компанії в } \\
\text { зіставленні з величиною вкладеного капіталу }\end{array}$ \\
\hline
\end{tabular}

Джерело: побудовано авторами за даними [2; 4; 5]

Оцінка ефективності фуннкій управління здійснюеться агрегуванням показників експертних оцінок. Коефіціент ефективності і-й фонкціі на основі вхідних обчислюеться за формулою:

$$
\ni_{i}=\frac{\sum K_{i j}}{n},
$$

де $K_{i j}$ - оцінка ефрективності функції управління $i$-й фрункції $j$-м експертом; $n$ - кількість експертів.

Така модель може застосовуватися для моніторингу поточного стану ефективності системи управління як підприемства в цілому, так і його структурних підрозділів. Вона також дозволяе проводити діагностику динаміки цих параметрів.

На етапі системної діагностики підприемства проводиться:

- аналіз чинників зовнішнього та внутрішнього середовища, причинно-наслідкових зв'язків на основі системного підходу;

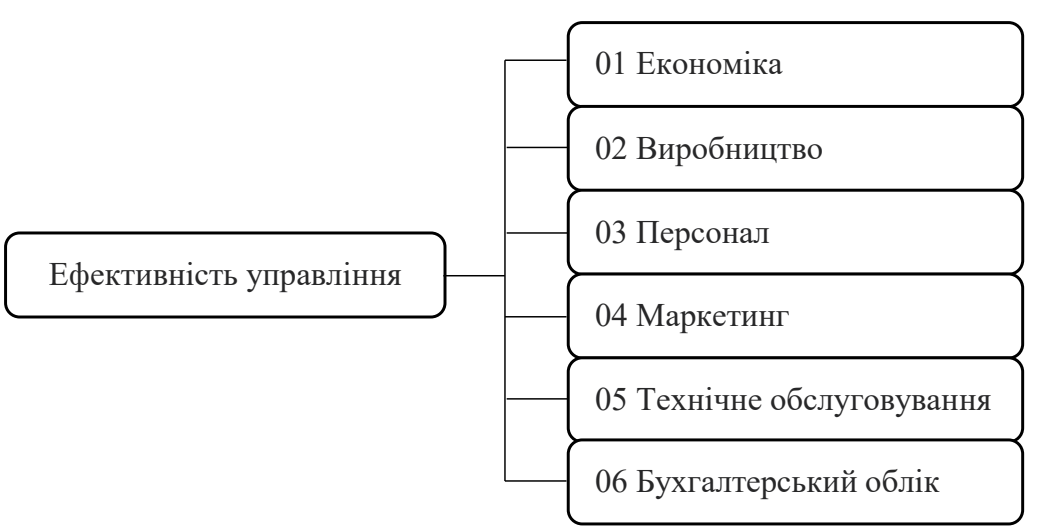

Рис. 4. Перший рівень дерева функцій управління підприемством
- економіко-математичне моделювання причинно-наслідкових зв'язків;

- аналіз потенціалу розвитку та формування прогнозних моделей;

- формування інституційної бази показників підприемства, в тому числі для виявлення закономірностей розвитку підприемства і прогнозування фінансово-економічного стану.

На етапі системної діагностики проводиться аналіз ефективності організаційної структури підприемства на основі сформованих корпоративних норм. Він передбачає ощінку ефективності управлінських рішень, ощінку потенщіалу наявних ресурсів і основних економічних інститутів підприемства, актуалізованих в його інституційних нормах, цінностях, фiлософфiї та місії.

Оцінка економічного потенціалу розвитку є багаторівневим і багатоаспектним об'єктом дослідження, включає в себе сукупність кадрових, фінансових, виробничих, інноваційних, інформаційних та інших потенціалів підприемства. При цьому вважається, що всі бізнес-процеси підприемства спрямовані на забезпечення довгострокового економічного розвитку в рамках обраної стратегії розвитку.

Діагностика на даному етапі передбачае виявлення, ідентифікацію та класифрікацію нових чинників, які обумовлюють динаміку параметрів фонкціонування підприемства. Параметри цих нових виявлених чинників включаються в систему моніторингу стану підприемства.

Розвиток механізмів контролю (м'який або жорсткий контроль, ла- 
тентний контроль тощо) показників стану підприемства проводиться на основі фрункцій контролінгу - комплексу характеристик управління, що відображають його типологічну приналежність до технології розробки управлінських рішень. Цей процес вимагае інтеграції обліку, аналізу, нормування, планування, контролю в загальній системі інформаційного та методичного забезпечення управління. Іншими словами, контролінг - система аналітичного постійного (попереджувального) контролю за фрункціонуванням бізнес-процесів і зовнішнього середовища підприемства.

Висновки і пропозиції. Таким чином, втрату економічної сталості підприемства у рамках антикризового управління можна діагностувати за допомогою різних методів та інструментів. При цьому необхідно враховувати сучасні підходи в антикризовому управлінні, які передбачають системність, процесність та синергію. Системність в антикризовому управлінні передбачає ієрархію зв'язків за цілями, завданнями та шляхами вирішення проблеми відновлення економічної сталості та налагодження стейкхолдерських відносин. Процесність полягає у логіці пошуку вирішення проблем, які перешкоджають функціонуванню та розвитку бізнесу, виявленню нових перспектив самоорганізащії виходу з кризи. Синергія проявляеться в мультиплікації результатів самооцінки, самоорганізації та розвитку підприемства.

Зміна акцентів у зовнішньому середовищі 3 порядку, логічності на невизначеність та хаос обумовлює трансформацію підходів до побудови системи підприємства, завдань антикризового управління, зміни цінності знань та досвіду на цінність навичок та потенціалу працівників.

Узагальнені авторами підходи до діагностування діяльності підприемства можуть дозволити їх керівництву подолати кризовий стан та забезпечити сталий збалансований розвиток, враховуючи індивідуальні особливості та стартові умови розвитку підприемства.

\section{Список літератури:}

1. Князева О.А., Кишинець Б.А. Методичні підходи до діагностики кризового стану підприемства. Вісник ОНУ імені I.I. Мечникова. 2018. Т. 23. Вип. 4(69). С. 64-69.

2. Методичні підходи до стратегічного управління діяльністю підприемства : монографія / П.П. Микитюк, В.Я. Брич, М.М. Федірко та ін. ; за заг. ред. П.П. Микитюка. Тернопіль : ТНЕУ, 2017. 399 с.

3. Плужников В.Г., Шикина С.А. Антикризисное управление : учебное пособие ; под ред. В.Г. Мохова. Челябинск : Издательский центр ЮУрГУ, 2016. 112 с.

4. Савчук В.П. Практическая әнциклопедия финансового менеджера. Київ : Баланс Бизнес Букс, 2017.976 с.

5. Старинець О.Г. Антикризове управління телекомунікаційними підприемствами: стан та перспективи розвитку : монографрія. Київ : Талком, 2018. 320 с.

6. Bacon T.R. What People Want: A Manager's Guide to Building Relationships That Work. 2016. 264 p.

7. Leigh M. Critical thinking in crisis management. 2016. $22 \mathrm{p}$.

8. Mocanu N. Implementation of anti-crisis management technologies. International Journal of Innovation in the Digital Economy (IJIDE). 2018. № 9(4). URL: https://www.igi-global.com/article/implementation-of-anti-crisismanagement-technologies/210614

\section{References:}

1. Kniazeva O., Kyshynest B. (2018) Metodychni pidkhody do diagnostyky kryzovogo stanu pidpryemstva [Methodical approaches to the diagnosis of the crisis of the enterprise]. Bulletin of I.I. Mechnikov ONU, vol. 23, no. 4(69), pp. 64-69.

2. Mykytiuk P., Brych V., Fedirko M. (2017) Metodychni pidkhody do strategichnogo upravlinnia diialnistiu pidpryemstva [Methodical approaches to strategic management of the enterprise]. Ternopil: TNEU. (in Ukrainian)

3. Pluzhnikov V., Shykyna S. (2016) Anrikrizisnoe upravlenie [Anti-crisis management]. Cheliabinsk. (in Russian)

4. Savchuk V. (2017) Prakticheskaia entsyklopediia finansovogo menedzhera [Practical encyclopedia of the financial manager]. Kyiv: Balance Business Books. (in Russian)

5. Starynets O. (2018) Antykruzove upravlinnia telekomunikatsiinymy pidpryemstvamy: stan ta perspektyvy rozvytku [Anti-crisis management of telecommunication enterprises: state and prospects of development]. Kyiv: Talkom. (in Ukrainian)

6. Bacon T. (2016) What People Want: A Manager's Guide to Building Relationships That Work.

7. Leigh M. (2016) Critical thinking in crisis management.

8. Mocanu N. (2018) Implementation of anti-crisis management technologies. International Journal of Innovation in the Digital Economy (IJIDE), no. 9(4). Available at: https://www.igi-global.com/article/implementation-of-anticrisis-management-technologies/210614 (accessed 10 December 2020). 